The University of Maine

DigitalCommons@UMaine

Publications

Senator George J. Mitchell Center for Sustainability

Solutions

$1-2015$

\title{
Will Offshore Energy Face "Fair Winds and Following Seas"?: Understanding the Factors Influencing Offshore Wind Acceptance
}

Mario f. Teisl

University of Maine - Main, teisl@maine.edu

Shannon K. McCoy

University of Maine

Sarah J. Marrinan

Caroline L. Noblet

University of Maine, caroline.noblet@maine.edu

Teresa R. Johnson

University of Maine - Main, teresa.johnson@maine.edu

See next page for additional authors

Follow this and additional works at: https://digitalcommons.library.umaine.edu/

mitchellcenter_pubs

Part of the Natural Resource Economics Commons, Oil, Gas, and Energy Commons, and the Sustainability Commons

\section{Repository Citation}

Teisl, Mario f.; McCoy, Shannon K.; Marrinan, Sarah J.; Noblet, Caroline L.; Johnson, Teresa R.; Wibberly, Megan; and Klein, Sharon, "Will Offshore Energy Face "Fair Winds and Following Seas"?: Understanding the Factors Influencing Offshore Wind Acceptance" (2015). Publications. 59.

https://digitalcommons.library.umaine.edu/mitchellcenter_pubs/59

This Article is brought to you for free and open access by DigitalCommons@UMaine. It has been accepted for inclusion in Publications by an authorized administrator of DigitalCommons@UMaine. For more information, please contact um.library.technical.services@maine.edu. 
Authors

Mario f. Teisl, Shannon K. McCoy, Sarah J. Marrinan, Caroline L. Noblet, Teresa R. Johnson, Megan

Wibberly, and Sharon Klein

This article is available at DigitalCommons@UMaine: https://digitalcommons.library.umaine.edu/mitchellcenter_pubs/59 
Will Offshore Energy Face "Fair Winds and Following Seas"?: Understanding the Factors Influencing Offshore Wind Acceptance

Mario F. Teisl, Shannon McCoy, Sarah Marrinan, Caroline L. Noblet, Teresa Johnson, Megan Wibberly, Robert Roper, Sharon Klein

M. F. Teisl, C. L. Noblet, S. Klein

School of Economics, University of Maine, Orono, ME 04469, USA

e-mail: teisl@maine.edu

S. McCoy

Department of Psychology, University of Maine, Orono, ME 04469, USA

S. Marrinan

US EPA National Center for Environmental Economics, Washington, DC, USA

T. Johnson

School of Marine Sciences, University of Maine, Orono, ME 04469, USA

M. Wibberly

Island Institute, Maine, Rockland, ME 04841, USA

R. Roper

Business Administration, University of Maine-Augusta, Augusta, ME 04330, USA 


\section{ABSTRACT}

Most offshore energy studies have focused on measuring or explaining people's perceptions of, and reactions to, specific installations. However, there are two different types of acceptance: one surrounds the siting of projects while the other surrounds a more general acceptance of offshore energy. Understanding what drives this second type of acceptance is important as governments have implemented new financial incentives and policies to support renewable energy development; however, citizens and government officials may be increasingly opposed to some of these support mechanisms. Our paper fills a void in the literature by using regression approaches to better understand how people's evaluations of the benefits and costs of offshore wind impact their level of general acceptance for offshore wind, while controlling for other factors (e.g., demographics). This analysis should help policy makers, and individuals attempting to educate the general public about renewable energy, to better understand the important factors influencing people's support or opposition to offshore wind energy initiatives.

Keywords: Offshore wind power, Public acceptance 


\section{INTRODUCTION}

Several authors have indicated a lack of scientific research focused on understanding the factors driving acceptance or opposition to renewable energy (Firestone et al. 2009, 2012; Firestone and Kempton 2007; Wolsink 2007;Devine-Wright 2005), especially as it relates to offshore wind (Haggett 2011). However, Wolsink (2010) and Firestone et al. (2009) point out that there are two different types of acceptance: one surrounds the siting of specific projects, which is inherently more local, while the other surrounds a more general acceptance of offshore wind energy.

The small literature on preferences for marine-based power has primarily focused on using specific simulated (Bishop and Miller 2007; Ladenburg and Dubgaard 2009) oractual/proposed projects (e.g., see Krueger et al. 2011; Wolsink 2010; Ladenburg 2009, 2008;Firestone and Kempton 2007; McCartney 2006) during project siting (first support type). This is not surprising in that opposition to offshore wind projects is usually in response to a specific local installation (Waldo 2012; Firestone and Kempton 2007; Kempton et al. 2005), and while general acceptance of these projects is widespread (Ladenburg 2010; Carrington 2012; Chervinsky 2006 as cited in Firestone and Kempton 2007), local opposition can derail the siting of wind projects (Kempton et al. 2005).

However, the second support type (general acceptance) is also important to understand, as state governments have developed institutions and policies to support renewable energy development, e.g., 417 state-level financial incentives and 281 policies to support renewable energy projects (DSIRE 2012a, b). In Maine, the state passed a law modifying the state's regulatory process to encourage appropriately sited renewable energy projects, the permitting and financing of these projects, the designated areas of the state for expedited permitting, and the 
establishment of a fund used to support renewable energy projects and to fund rebates for renewable energy installations (see MRSA 35-A). A posting on the National Wind Watch Website (NWW 2011) and articles in Maine papers (Schalit 2010) indicate an increasing opposition to some of these structural changes, especially related to the expedited review process.

Given the above, our main research objective is to use quantitative approaches to better understand how people's evaluations of the benefits and costs of offshore wind impact their level of general acceptance for offshore wind, while controlling for other factors (e.g., demographic) that may explain their level of acceptance. This analysis should help policy makers and individuals attempting to educate the general public about renewable energy, to better understand the important factors influencing people's acceptance, or opposition, to offshore wind energy initiatives.

The Maine Context

Located in the extreme northeast of the USA, Maine is primarily rural with a relatively low population density (about 42 people per square mile). Maine's major industries revolve around its abundant natural resources: agriculture and forestry in the inland regions, and fishing, aquaculture, and tourism along the ocean coast. For example, during 2012, Maine commercial landings totaled over $\$ 300$ million, with lobster (40\%) and Atlantic herring (29\%) being the primary products and the remaining include seaweed, shell-and ground-fish, shrimp, and urchins (DMR 2012). Although Maine's ocean coast is around 250 miles as measured in a straight line, it has numerous inlets, peninsulas, rocky headlands, and bays, making the true coastline over 3,500 miles. Maine also has over 6,500 islands, some inhabited year-round, others only seasonally or are used for recreation (e.g., the Maine Island Trail which connects over 200 island and mainland sites for day and overnight camping visits; see http://www.mita.org/trail). Given its recreational, 
artistic, and commercial uses, management of the Maine coast is important to Maine's culture, economy, and environment. So it is not surprising that commercial development along the coast can be highly contentious; for example, a recent proposal to build a $\$ 50$ million import terminal for propane was canceled due to local resident concerns about safety, property values, and impacts on tourism (Seelye 2013).

Although Maine leads New England in developing onshore wind (American Council on Renewable Energy 2010), the state is looking offshore toward the Gulf of Maine, where there are strong consistent winds (Island Institute 2012). Maine has set an ambitious target of producing 5 GW of electricity from offshore wind turbines by 2030 to bring more clean energy to meet mainland demand as well as to help meet the demand of Maine's numerous offshore islands.

The recent research and political activities surrounding offshore wind development has increased local media attention. For example, our search of the Maine Newsstand (an online database) for newspaper articles with the words "offshore wind" and "energy" indicates that there were only four articles published before 1/1/2008, 202 articles published between 1/1/2008 and 5/1/2010 (the start of our survey administration), and 352 articles between 5/1/2010 and 11/1/2013. These media stories have become increasingly politicized, with supporters highlighting positive (e.g., economic development) and opponents focusing on negative (e.g., cost of subsidies) aspects of offshore wind (Acheson 2012).

\section{LITERATURE}

Most papers studying wind power acceptance focus on specific existing or proposed development sites and include variables (e.g., engagement processes used by the developers; Haggett 2011; Wolsink 2007) which, although important, are less pertinent to this study of general 
offshore wind power acceptance. Further, most of the literatures (e.g., Wolsink 2010; Bishopand Miller 2007; Ladenburg 2008, 2009, 2010; Ladenburg and Moller 2011; Lilley et al. 2010)examine only one facet of offshore wind, specifically, concerns due to disruptions to viewscapes, who is affected and how distance can mitigate this concern. As Firestone et al. (2009,p. 184) state, "while much has been written about support and opposition of wind farms, complex analyses of the factors... that underlie... support and opposition have been, for the most part, lacking." Most pertinent to the research here are papers examining how perceptions of energy development, and the characteristics of the individual, influence acceptance for offshore wind.

Perceptions of Potential Benefits and Concerns

In examining the perceptions of supporters and opponents of offshore wind farms, Firestone and Kempton (2007)and Firestone et al. $(2009,2012)$ find that acceptance increases when respondents believe the wind farm benefits include improved air quality, increased economic development and jobs, and decreased electricity prices. They also find acceptance decreases when respondents believe the wind farm will result in declining property values, lowered aesthetics, negative fishing impacts, decreased tourism, reduced boating safety, and increased electricity prices. People who perceive offshore wind farms have negative effects on viewscapes (Krueger et al. 2011; Devine-Wright 2005) and bird and marine life (Firestone and Kempton 2007; Ladenburg and Moller 2011; Ladenburg 2008) are also more negative toward offshore wind farms.

Individual Characteristics

Acceptance of offshore wind decreases with increases in education (Krueger et al. 2011), income (Ladenburg 2010; Ladenburg and Moller 2011; Firestone and Kempton 2007), and age 
(Krueger et al. 2011; Ladenburg and Moller 2011; Firestone and Kempton 2007). Males are also found to be less positive toward offshore wind (Ladenburg 2010; Ladenburg and Moller 2011). Place identity, as measured by the percent of a person's life lived in a region, has been shown to affect a person's preference for land versus offshore wind power; an increase in place identity was associated with a preference for land-based wind (Marrinan 2012).

METHODS AND DATA

This study uses a mail survey approach to study people's acceptance of offshore wind power and the factors that would impact this acceptance in Maine.

Sampling and Data Collection

During the summer of 2010, we administered two different versions of a statewide survey to three separate samples of Maine (USA) adult residents, asking questions about offshore wind. The three samples are: 600 citizens who currently live near existing on-land wind facilities (land sample), 600 citizens who live near the coast where offshore facilities are currently being proposed (coast sample), and the 1,800 citizens not living in the areas contained in the coast and land samples (general sample). Although we pool these data, we control for differences across the samples in our analysis.

The survey was administered in a two-round modified Dillman et al. (2009) method between April and August of 2010. Each round after the initial introduction letter presented the participant with a copy of the survey, a cover letter, and a $\$ 1$ cash incentive; the response rate was $47 \%$. Our respondents have slightly higher incomes and education levels, are older and more likely to be male than the general Maine population. To correct these demographic differences and to correct 
for the oversampling of people living on the coast or near land-based wind farms, we weight the data according to gender, age, education, income, and place of residence. The descriptive results (Tables 1 and 2) are weighted and the regression results (Table 3) are from weighted regressions.

Survey Design

The survey instrument consists of five sections. Section I solicits respondents' background knowledge about wind energy in Maine. In Section II, respondents are asked to express their views on potential benefits and concerns of wind power (Table 2). Section III contains six alternative informational messages about wind energy potential in Maine, followed by six questions to measure people's reactions to the information. Section IV collects information on a respondent's attitudes and behaviors. The final section consists of demographic questions.

Regression Analysis

We model the factors that influence respondents' acceptance for offshore wind power. These factors include respondents' importance ratings of various potential offshore wind power benefits and concerns, and other factors (e.g., the respondent's experiences with wind farms, participation in marine-based recreation, and demographics).

Specifically, we estimate a model with the general form of:

$$
\begin{gathered}
I N D E X=\alpha+\sum_{j} \beta_{j}\left(\operatorname{TREAT}_{j}\right)+\sum_{k} \beta_{k}\left(B \& C_{k}\right)+\sum_{h} \beta_{h}\left(\operatorname{CONT}_{h}\right)+ \\
\sum_{m} \beta_{m}\left(E X P_{m}\right)+\sum_{n} \beta_{n}\left(\text { MREC }_{n}\right)+\sum_{p} \beta_{p}\left(D E M_{p}\right)+\mu
\end{gathered}
$$

where the dependent variable, INDEX, is framed as a public (Homo politicus) acceptance for wind 
(Nyborg 2000). The importance of frame is suggested in the wind energy acceptance literature; for example, Firestone et al. (2009)makes a distinction between "market acceptance, local community acceptance, and socio-political acceptance, the last of which includes acceptance of the public, key stakeholders, and policy makers" (p. 188). Presumably our INDEX measures sociopolitical acceptance.

INDEX, is constructed as the average response of three questions: "How do you feel about wind energy?" ( $0=$ negative, $6=$ positive); "In your opinion, is wind power a good solution for Maine's energy problems? ( $0=$ not a good solution, $6=$ =very good solution); and "Would you encourage wind power development in Maine?" ( $0=$ not likely, $6=$ =very likely). The model which is estimated using ordinary least squares regression as INDEX can be considered continuous interval data, because an index of multiple Likert (ordinal) responses can be treated as interval data if it passes the Cronbach's alpha test of inter-correlation (Allen and Seaman 2007). Here, the alpha score is 0.95, which is quite high, meeting the standard of excellent (Kline 1999).

The questions used to construct the index are from the information messaging experiment (Section III) in the survey; there were a total of six potential messages that respondents could see prior to responding to the questions included in INDEX. ANOVA testing indicates there are no differences in the responses to the "How do you feel about wind energy?" $\left(F_{5,394}=1.65 ; p=0.15\right)$ and "In your opinion, is wind power a good solution for Maine's energy problems?" $F_{(5,395)}=1.23$; $p=0.30$ ) across the six treatments. However, there is a difference in the responses to the "Would you encourage wind power development in Maine?" $\left(F_{(5,394)=1.90 ; p=0.09)}\right.$ across the six treatments. As such, we added several variables to the model (TREAT) to control for any potential that INDEX was affected by the information treatments.

B\&C denotes respondents' importance ratings of nine benefits and nine concerns (Table 2) potentially associated with offshore wind farms (rated on a five-point Likert scale, where 1="not 
at all important," 3= "somewhat important," and 5="very important"). Several of the B\&C variables parallel those listed in Firestone and Kempton (2007) and Firestone et. al (2009, 2012), although the method of data collection differs. For example, they provided respondents with 11 potential impacts of an offshore wind farm and asked them to indicate whether they thought the impact would be positive, negative, have no impact, or if they were not sure. They then asked respondents to rank which of the 11 impacts would be the three most important in their decision to support or oppose the wind farm development. Here, we provided a list of 18 benefits and concerns and asked respondents to rate the importance of each. In our model, we assume the importance evaluations of the benefits and costs are made prior to making the decision to accept wind power; thus, these are predetermined endogenous variables in the models.

CONT denotes a vector of variables included to control for general variation in the data due to sample (general, LAND, and COAST samples). Given the exact linear relationship across the sample variables, we need to drop one variable to avoid the "dummy variable trap." As a result, we dropped the variable denoting the general sample; in turn, the coefficient on the remaining sample variables denotes the difference in the effect between that sample and the base of "general sample."

EXP denotes a vector of variables measuring respondent experience with wind farms, which we include in the model because studies indicate that seeing land-based and offshore wind farms increases their acceptance (Ladenburg 2010; Ladenburg and Moller 2011). We used three questions to measure respondent experience/ knowledge with wind farms (Table 1); each question required a YES (coded 1) or NO (coded 0) response. MREC denotes a vector of variables (Table 1) measuring the respondent's participation in marine-based recreation, which has been shown to be important in some site-specific studies (Ladenburg Ladenburg and Dubgaard 2009). To measure this participation, we asked respondents to indicate (from a list) whether they 
participated in various outdoor activities during the last year. For this analysis, we included variables measuring if the respondent participated in marine-based power boating, sailing, fishing, or kayaking (coded 1 if participated; 0 otherwise). DEM denotes a vector of weighted demographic variables (Table 1); specifically, we examine the respondent's gender (1=male; $0=$ female), age and education levels, household income (\$), and the percent of their life residing in Maine (years living in Maine/age). The latter variable is a coarse measure of a respondent's place identity (Williams and Vaske 2003). $\mu$ is an error term.

\section{RESULTS AND DISCUSSION}

The results are presented in the following manner. To provide context, we first provide a descriptive overview of the relative importance of the benefits and costs potentially associated with offshore wind projects. We then examine the regression explaining general acceptance for offshore wind as a function of the benefits, costs, and other factors. When appropriate, we make comparisons with the Firestone and Kempton (2007) and Firestone et al. $(2009,2012)$ papers.

On average, the potential benefits of offshore wind are relatively more important to respondents than the potential costs (Table 2). The four benefits earning the highest importance ratings are a mix of economic, environmental, and fuel security issues, and the top three benefits are very similar to the three positive impacts found by the three Firestone papers: job creation, electricity rates, and air quality. Unlike the top four negative impacts found by Firestone and Kempton (ocean aesthetics, community harmony, fishing industry, and marine recreation), we find that the top four important concerns are generally economic in nature (note the concern about wind power's negative marine life impacts may partially reflect economic concerns related to Maine's fishing industry). The concerns usually highlighted in the literature as being very important in the siting of specific wind power projects (e.g., noise and viewscape disruptions) are 
still important, but are rated relatively less important by our respondents. This result may be due to the nature of the offshore wind discourse in the state (focusing on offshore wind projects being more than 20 miles offshore), or due to the framing of our survey (focusing on wind power acceptance in general, as opposed to a specific wind project).

In general, the significant benefit and concern regression coefficients have the expected signs, i.e., increased importance placed on potential benefits (allows Maine to export electricity, decreases global warming, reduces local property taxes, and decreases fossil fuel imports), increased wind power acceptance while increased importance was placed on potential concerns (increases electricity prices, decreases coastal property values, disrupts working waterfronts and degrades scenic views), and decreased wind power acceptance (Table 3).

However, the significant coefficients are attached to some economic (allows Maine to export electricity) and environmental (decreases global warming) benefits, and some economic (decreases coastal property values) and aesthetic (degrades scenic views) concerns that are ranked relatively low in importance (see Table 2). Specifically, "allows Maine to export electricity" and "decreases global warming" are ranked as the 8th and 6th most important benefits, and "decreases coastal property values" and "degrades scenic views" are ranked as the 9th and 8th most important concerns. Note that these have some overlap with the positive (e.g., air quality and increased renewable energy) and negative (e.g., property values and aesthetics) regression results found in Firestone and Kempton.

Because the benefit and concern variables are in the same metric, we can test to see if there are differences across the significant benefit and concern coefficients. This testing provides additional information about the relative strength of these coefficients. We find that in the global warming,

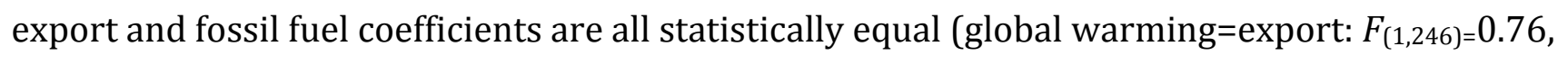
$p=0.38$; global warming=fossil fuel: $F_{(1,246)}=0.04, p=0.83$; export=fossil fuel: $F_{(1,246)}=0.33, p=0.57$ ), 
whereas the property tax coefficient is different than the global warming and fossil fuel coefficients (property tax=global warming: $F_{(1,246)}=3.70, p=0.06$; property tax=fossil fuel: $F_{(1,246)}=2.72, p=0.10$ ) but equal to the export coefficient (property tax=export: $F_{(1,246)}=1.63$, $p=0.20$ ). We also find that all the significant concern coefficients are statistically equal (electricity price=working waterfront: $F_{(1,246)}=0.01, p=0.94$; electricity price=property values: $F_{(1,246)}=0.02$, $p=0.88$; electricity price=views: $F_{(1,246)}=0.02, p=0.88$; property values=working waterfront: $F_{(1,246)}=0.00, p=0.95$; property values=views: $F_{(1,246)}=0.09, p=0.79$; working waterfront=views: $\left.F_{(1,246)}=0.04, p=0.83\right)$.

Interestingly, the level of acceptance for offshore wind is not necessarily related to the relative importance ratings of the benefits and concerns. For example, three of the most important benefits-lowering electricity prices, decreasing air pollution, and increasing employment (Table 2) - are not significant in altering peoples' acceptance for offshore wind (Table 3), while a benefit rated rather low (e.g., Maine can export wind power) does impact people's acceptance of offshore wind power. Although the most important concern to respondents (increasing electricity prices) had a significant impact on offshore wind acceptance, some of the lowest rated concerns, (e.g., degradations in viewscapes and lowering of property values) also had significant negative impacts on offshore wind acceptance.

These results highlight that a person's acceptance for offshore wind power is not necessarily related to the perceived importance of particular wind power attributes, on average. For example, lowering electricity prices may be relatively more important, on average, than viewscape degradation, but people who place different levels of importance on lower prices are equally accepting of offshore wind, whereas people who place different levels of importance on viewscapes have very different levels of acceptance for offshore wind. In other words, people with very different views of the importance of price may still agree on whether to accept offshore wind; 
whereas people with very different views of the importance of viewscapes are likely to disagree on whether to accept offshore wind. Taking this result and using it in a marketing/education campaign means that changing the level of acceptance for offshore wind power is best done by focusing on benefits and concerns that are shown to be significantly linked to changing acceptance.

Individuals who are interested in altering people's acceptance for offshore wind development could use the preceding results for direction. For example, in Table 3, we see that the "fossil fuel imports" and "global warming" coefficients are relatively large, meaning that a change in these variables have, on average, relatively large impacts on changing people's acceptance for offshore wind power. However, from Table 2, we see that the average importance rating for both these variables is already relatively high. As a result, we hypothesize that it may be easier to provide information about offshore wind that decreases these ratings rather than increasing them. So a group opposed to offshore wind subsidies may find it effective to provide information about how offshore wind will not reduce fossil fuel imports or help fight climate change. Conversely, advocates of offshore wind support policies could effectively spend their resources to show how offshore wind will not lead to increased electricity prices nor will it lead to degraded views or recreation.

Acceptance of offshore wind power was not different across sample type or information treatments. Specifically, the coefficients from the coast and land-based wind samples are not different than the baseline "general" sample; and the coast and land-based wind coefficients are not different from each other $\left(F_{(1,246)}=0.00 ; p=0.99\right)$. With respect to the TREAT results, we find that the parameter estimates for the five information treatments are not different from the omitted treatment and that testing across the five treatment parameters indicates that they are not different from each other. Finally, we ran regressions with and without the treatment 
variables and find the suite of variables adds nothing to the model fit $\left(F_{(5,243)}=1.067, p=0.38\right)$.

When considering the demographic and experience factors affecting how people evaluate offshore wind power, we derive similar findings to the cited literature, i.e., being male and more educated decreases the acceptability of offshore wind power.

\section{CONCLUSIONS}

Current state and federal policies that incentivize offshore wind provide similar incentives for other renewable energy sources that are already commercially operational, lower cost, and less risky to investors (e.g., land-based wind, landfill gas, municipal solid waste, and hydroelectric). Currently, offshore wind will require additional policy support in order to overcome market barriers and become commercially competitive. At the time of this data collection, most Maine citizens were supportive of the state's efforts to develop commercial-scale offshore wind power; for example, of those who favor a specific type of wind power, most (64\%) favored offshore wind. Our results also indicate that there may be public acceptance of state policies that specifically target offshore wind energy and their unique needs, particularly, if these energy sources provide clear fuel security and environmental benefits. However, the results also indicate a strong potential that acceptance of wind power will erode if wind power leads to economic, commercial, or aesthetic losses. The fact that we find no significant difference in how people evaluate offshore wind across space (e.g., distance from coast and lives near current land-based wind farm) indicates that Maine citizens are relatively uniform in their acceptance of offshore wind no matter where they live, suggesting that acceptance is not a NIMBY phenomenon (see Haggett 2011).

Our study contributes to the few studies that examine the wide range of benefit and concern factors that could impact acceptance for offshore wind. Future studies should evaluate public acceptance for policies that encourage local development of these precommercial renewable 
energy options and pay close attention to the diverse factors that could affect acceptance.

Comparison of citizen acceptance of policies designed to incentivize renewable energy production with other environmental policies designed to address global climate change impacts (e.g., the Northeast's Regional Greenhouse Gas Initiative) may also illuminate results in future work. 


\section{ACKNOWLEDGMENTS}

Funding was provided by the Maine Sustainability Solutions Initiative, the National Science Foundation Grant EPS0904155 to Maine EPSCoR at the University of Maine, and the Maine Agriculture and Forest Experiment Station. 


\section{FIGURES}

Table 1 Characteristics of respondents; data weighted by gender, age, education, income, and residency

\begin{tabular}{|c|c|c|}
\hline Respondent's experience with wind farms & Respondents & Census $^{\mathrm{a}}$ \\
\hline \multicolumn{3}{|l|}{ Percent of respondents stating yes to: } \\
\hline $\begin{array}{l}\text { Have you seen any of Maine's land-based } \\
\text { wind farms? }\end{array}$ & 38 & \\
\hline $\begin{array}{l}\text { Have you ever been asked to vote on a wind- } \\
\text { farm-related permit or vote on a change to } \\
\text { your town's ordinances for the sake of } \\
\text { allowing or restricting wind farms in your } \\
\text { town? }\end{array}$ & 4 & \\
\hline $\begin{array}{l}\text { Did you know that there are plans to develop } \\
\text { offshore wind farms in Maine? }\end{array}$ & 76 & \\
\hline \multicolumn{3}{|l|}{ Marine recreation characteristics } \\
\hline Percent power-boating on ocean & 9 & \\
\hline Percent sailing on the ocean & 4 & \\
\hline Percent marine fishing & 12 & \\
\hline Percent sea-kayaking & 5 & \\
\hline \multicolumn{3}{|l|}{ Socio-demographic characteristics } \\
\hline Gender (percent male) & 49 & 49 \\
\hline Average age (years) & 49 & 48 \\
\hline Average education (years) & 13.9 & 13.8 \\
\hline Percent of life living in Maine & 77 & \\
\hline Average household income & $\$ 59,600$ & $\$ 59,300$ \\
\hline
\end{tabular}

${ }^{\mathrm{a}}$ Data from the US Census Bureau 
Table 2 Respondent importance placed on potential benefits and concerns with offshore wind; data weighted by gender, age, education, income, and residency

Average

importance $^{\mathrm{a}}$

$\begin{array}{ll}\text { Benefits } & \\ \text { Decreases the average price of electricity } & 4.41 \\ \text { Decreases Maine's air pollution } & 4.33 \\ \text { Increases local employment } & 4.32 \\ \text { Decreases Maine's fossil fuel imports } & 4.26 \\ \text { Reduces local property taxes } & 4.13 \\ \text { Decreases global warming } & 4.02 \\ \text { May enhance fish habitat } & 3.96 \\ \text { Maine can export wind power } & 3.67 \\ \text { Increases coastal tourism } & 3.33 \\ \text { Concerns } & \\ \text { Increases the average price of electricity } & 4.16 \\ \text { Increases risks to marine life } & 4.03 \\ \text { Limits commercial fishing areas } & 3.63 \\ \text { Disrupts working waterfront } & 3.37 \\ \text { Degrades marine and coastal recreation } & 3.42 \\ \text { Increases navigational risks } & 3.28 \\ \text { May cause noise and vibrations heard from } & 3.06 \\ \text { shore } & 3.04 \\ \text { Degrades scenic views } & 2.89 \\ \text { Decreases coastal property values } & \end{array}$

a Responses range from 1="not at all important," 3="somewhat important" to 5= "very important" 
Table 3 Regressions explaining respondent support for offshore wind power, ${ }^{a}$ data weighted by gender, age, education, income, and residency

\begin{tabular}{|c|c|c|}
\hline & \multicolumn{2}{|c|}{ Public support index ${ }^{b}$} \\
\hline & $B$ & $\begin{array}{l}\text { Std. } \\
\text { error }\end{array}$ \\
\hline Intercept & $9.766^{\circ *}$ & 1.771 \\
\hline \multicolumn{3}{|c|}{ Potential benefits (ordered by most to least importance rating - see Table 2) } \\
\hline Decreases the average price of electricity & 0.253 & 0.156 \\
\hline Decreases Maine's air pollution & -0.053 & 0.225 \\
\hline Increases local employment & -0.016 & 0.206 \\
\hline Decreases Maine's fossil fuel imports & $0.643 y^{\cdots *}$ & 0.150 \\
\hline Reduces local property taxes & $0.293_{x} *$ & 0.141 \\
\hline Decreases global warming & $0.692 y^{\cdots \cdots}$ & 0.167 \\
\hline May enhance fish habitat & -0.017 & 0.138 \\
\hline Maine can export wind power & $0.519_{x y}{ }^{\cdots * *}$ & 0.121 \\
\hline Increases coastal tourism & 0.106 & 0.140 \\
\hline \multicolumn{3}{|c|}{ Potential costs (ordered by most to least importance rating - see Table 2 ) } \\
\hline Increases the average price of electricity & $-0.365_{z}{ }^{* * *}$ & 0.140 \\
\hline Increases risks to marine life & -0.089 & 0.188 \\
\hline Limits commercial fishing areas & -0.048 & 0.157 \\
\hline Disrupts working waterfront & $-0.383_{z}^{*}$ & 0.173 \\
\hline Degrades marine and coastal recreation & -0.243 & 0.158 \\
\hline Increases navigational risks & 0.240 & 0.157 \\
\hline May cause noise and vibrations heard from shore & 0.134 & 0.127 \\
\hline Degrades scenic views & $-0.333_{z} \ddot{ }$ & 0.155 \\
\hline Decreases coastal property values & $-0.396_{z}^{* * *}$ & 0.120 \\
\hline \multicolumn{3}{|l|}{ Demographics and experience with wind } \\
\hline Respondent is male & $-0.531^{*}$ & 0.281 \\
\hline Age & -0.003 & 0.009 \\
\hline Years of education & $-0.192^{* * *}$ & 0.072 \\
\hline Percent of life lived in Maine & -0.435 & 0.440 \\
\hline Income & $1.66 \mathrm{E}-07$ & $3.09 \mathrm{E}-06$ \\
\hline Seen land-based wind farms & -0.115 & 0.265 \\
\hline \multicolumn{3}{|l|}{ Sample and treatment controk } \\
\hline Lives near coast & 0.485 & 0.431 \\
\hline Lives near land-based wind & 0.496 & 0.620 \\
\hline Saw growth message & 0.237 & 0.416 \\
\hline Saw security message & 0.560 & 0.408 \\
\hline Saw change message & 0.202 & 0.464 \\
\hline Saw gains message & 0.023 & 0.454 \\
\hline Saw losses message & -0.372 & 0.429 \\
\hline$N$ & 278 & \\
\hline$R^{2}$ & 0.64 & \\
\hline
\end{tabular}

${ }^{\mathrm{a}}$ Significance at ${ }^{*} 0.10 \%$ level, ${ }^{*} 0.05 \%$ level, and ${ }^{* *} 0.01 \%$ level; significant benefit and cost coefficients sharing a subscript are not significantly different from each other

${ }^{b}$ Index is a mean created from responses to three questions: How do you feel about wind energy? $(0=$ negative, $6=$ positive); In your opinion, is wind power a good solution for Maine's energy problems? $(0=$ not a good solution, $6=$ a very good solution); Would you encourage wind power development in Maine? $(0=$ not likely, $6=$ very likely $)$ 


\section{REFERENCES}

Acheson, J. 2012. Attitudes toward offshore wind power in the Midcoast Region of Maine. Maine Policy Review 21(2): 42-55.

Allen, E., and C.A. Seaman. 2007. Likert scales and data analyses. Quality Progress 40: 64-65.

American Council on Renewable Energy. 2010. Renewable Energy in Maine http://www.hpba.org/government-affairs/renewableenergy/ pdfs/Maine.pdf. Accessed 1 February 2014.

Anderson, M.W., C. Noblet, and M. Teisl. 2012. Our environment. A glimpse at what Mainers value. Maine Policy Review 21(1): 104-110.

Bishop, I.D., and D.R. Miller. 2007. Visual assessment of off-shore wind turbines: The influence of distance, contrast, movement and social variables. Renewable Energy 32: 814-831.

Carrington, D. 2012. Local opposition to onshore windfarms has tripled, poll shows. The Guardian (February 29).

Chervinsky, G.2006. The State House news poll, May.Boston, MA: State House News Service. http://www.statehousenews.com/.

Devine-Wright, P. 2005. Beyond NIMBYism: Towards an integrated framework for understanding public perceptions of wind energy. Wind Energy 7: 125-139.

Dillman, D.A., J.D. Smyth, and L.M. Christian. 2009. Internet, mail and mixed-mode surveys: The tailored design methods, 3rd ed. Hoboken: Wiley.

DMR (Maine Department of Marine Resources). 2012. Preliminary 2012 commercial Maine landings by live pounds. http://www.maine.gov/ dmr/commercialfishing/documents/2012PoundsPie.pdf. Accessed 12 April 2013.

DSIRE (Database of State Incentives for Renewables and Efficiency). 2012a. Financial incentives for renewable energy. N.C. Solar Center, N.C. State University and the Interstate Renewable Energy Council. http://www.dsireusa.org/summarytables/finre.cfm. Accessed on 7 May 2012.

DSIRE (Database of State Incentives for Renewables and Efficiency). 2012b. Rules, regulations \& policies for renewable energy. N.C. Solar Center, N.C. State University and the Interstate Renewable Energy Council. http://www.dsireusa.org/summarytables/rrpre.cfm; Accessed on 7 May 2012.

EIA (US Energy Information Administration). 2012. Maine state profile and energy estimates. http://www.eia.gov/state/?sid=ME. Accessed 12 April 2013.

Firestone, J., and W. Kempton. 2007. Public opinion about large offshore wind power: Underlying factors. Energy Policy 35: 1584-1598.

Firestone, J., W. Kempton, and A. Krueger. 2009. Public acceptance of offshore wind power projects in the USA. Wind Energy 12: 183-202.

Firestone, J., W. Kempton, M.B. Lilley, and K. Samoteskul. 2012. Public acceptance of offshore wind power across regions and through time. Journal of Environmental Planning and Management 55(10): 1369-1386.

Haggett, C. 2011. Understanding public responses to offshore wind power. Energy Policy 39: 503510.

Island Institute. 2012. Economics of Offshore Wind Energy in Maine http://www.islandinstitute.org/documents/Economics_11x17_march21.pdf. Accessed 1 February 2014.

Johansson, M., and T. Laike. 2007. Intention to respond to local wind turbines: The role of attitudes and visual perception. Wind Energy 10: 435-451.

Kempton, W., J. Firestone, J. Lilley, T. Rouleau, and P. Whitaker. 2005. The offshore wind power debate: Views from Cape Cod. Coastal Management 33: 119-149. 
Kline, P. 1999. The handbook of psychological testing, 2nd ed. London: Routledge.

Krueger, A.D., G.R. Parsons, and J. Firestone. 2011. Valuing the visual disamenity of offshore wind power projects at varying distances from the shore: An application on the Delaware shoreline. Land Economics 87(2): 268-283.

Ladenburg, J. 2008. Attitudes towards on-land and off-shore wind power development in Denmark: Choice of development strategy. Renewable Energy 33: 111-118.

Ladenburg, J. 2009. Visual impact assessment of offshore wind farms and prior experience. Applied Energy 86(3): 380-387.

Ladenburg, J. 2010. Attitudes towards offshore wind farms-The role of beach visits on attitude and demographic and attitude relations. Energy Policy 38: 1297-1304.

Ladenburg, J., and B. Moller. 2011. Attitude and acceptance of offshore wind farms-The influence of travel time and wind farm attributes. United States Association for Energy Economics and the International Association for Energy Economics Working Paper, USAEE-IAEE WP 11-079.

Ladenburg, J., and A. Dubgaard. 2009. Preferences of coastal zone user groups regarding the siting of offshore wind farms. Ocean and Coastal Management 52: 233-242.

Lilley, B.L., J. Firestone, and W. Kempton. 2010. The effect of wind power installations on coastal tourism. Energies 3: 1-22.

Marrinan, S.J. 2012. Evaluating the influence of Maine residency on support for energy investments and private behavior: Two economic choice studies. M.S. thesis, The Graduate School, The University of Maine, August 2012.

McCartney, A. 2006. The social value of seascapes in the Jurien Bay Marine Park: An assessment of positive and negative preferences for change. Journal of Agricultural Economics 57(3): 577-594.

Miller, K. 2012. LePage's wind power stance stirs discomfort. Bangor Daily News 5/28.

Morison, S.L. 2012. US Department of the Navy, Naval Historical Center, Washington DC http://www.ibiblio.org/hyperwar/nhc/ fairwinds.htm. Accessed 3 July 2012.

MRSA 35-A (Maine Revised Statute Title 35-A). Public utilities heading: PL 1987, C. 141, Pt. A, §6 (new). http://www.mainelegislature.org/legis/statutes/35-A/title35-A.pdf. Accessed on 7 May 2012.

NWW (National Wind Watch). 2011. Groups opposed to Kibby wind project to protest LURC meeting January 4, 2011.

http://www.wind-watch.org/news/2011/01/04/groups-opposedto-kibby-wind-project-to-protest-lurc-meeting/. Accessed 9 May 2012.

Nyborg, K. 2000. Homo economicus and Homo politicus: Interpretation and aggregation of environmental values. Journal of Economic Behavior and Organization 42(3): 305-322.

Schalit N. 2010. Some who created wind-power fast track now questioning the goals they set. Bangor Daily News (Aug. 09).

http://bangordailynews.com/2010/08/09/news/some-who-createdwindpower-fast-track-now-questioning-the-goals-they-set/. Accessed 9 May 2012.

Seelye, K.Q. 2013. A proposal for a propane tank looms large over a Maine coastal town. The New York Times (Feb. 22, 2013). http:// www.nytimes.com/2013/02/23/us/proposed-propane-tank-cleavessearsport-me.html?pagewanted=all\&_r=0. Accessed 18 April 2012.

Smith, H., and L. Lindenfeld. In press. Making media studies engaged: A look at methods, approaches and opportunities for change. Environmental Communication: A Journal of Nature \& Culture.

Thøgersen, J., and C.L. Noblet. 2012. Does green consumerism increase the acceptance of windpower? Energy Policy 51: 854-862.

Waldo, A. 2012. Offshore wind power in Sweden-A qualitative analysis of attitudes with 
particular focus on opponents. Energy Policy 41: 692-702.

Williams, D.R., and J.J. Vaske. 2003. The measurement of place attachment: Validity and generalizability of a psychometric approach. Forest Science 49(6): 830-840.

Wolsink, M. 2007. Wind power implementation: The nature of public attitudes: equity and fairness instead of 'backyard motives. Renewable and Sustainable Energy Reviews 11: 1188-1207.

Wolsink, M. 2010. Near-shore wind power-protected seascapes, environmentalists' attitudes, and the technocratic planning perspective. Land Use Policy 27(2): 195-203. 